\title{
Synthesis and Crystal Structure of a Triply-Bridged Binuclear Cobalt(II) Dichloroacetate
}

\author{
M. GOGOI, S.J. BHARALI and B. K. DAS* \\ Department of Chemistry, Gauhati University, Guwahati-781014, Assam, India \\ birinchi.das@gmail.com
}

Received 20 July 2017 / Accepted 17 September 2017

\begin{abstract}
A triply-bridged cobalt(II) tetracarboxylate complex, $\left[\mathrm{Co}_{2}\left(\mu-\mathrm{OH}_{2}\right)\left(\mu-\mathrm{CHCl}_{2} \mathrm{COO}\right)_{2}\left(\eta^{1}-\right.\right.$ $\left.\left.\mathrm{CHCl}_{2} \mathrm{COO}\right)_{2}(\mathrm{py})_{4}\right]$ has been prepared and its crystal structure has been determined by single crystal $\mathrm{x}$-ray diffraction to find that in this dinuclear cobalt(II) complex, the two metal centres are bridged by a water molecule and two dichloroacetato ligands. Each $\mathrm{Co}$ (II) centre is further coordinated to one monodentate dichloroacetato and two pyridine ligands. Supramolecular interactions stabilize the complex in the solid state.
\end{abstract}

Keywords: Cobalt(II) dichloroacetate, Aqua-bridged complex, Crystal structure

\section{Introduction}

Metalloenzymes like hydrolases require closely coupled divalent metal ions for carrying out specific or selective hydrolytic reactions ${ }^{1}$. The presence of bridging oxo $^{2}$, hydroxo ${ }^{3}$ and aqua $^{4}$ groups in binuclear transition metal complexes play a crucial role in their catalytic behaviour. The metalloenzyme leucine aminopeptidase contains a dinuclear zinc core that has a water molecule and a carboxylate anion as bridging ligands, along with monodentate nitrogen-containing ligands at two ends. Therefore, the study of complexes with dimetallic units with carboxylate and aqua bridges is quite relevant. Such complexes have also been studied for magneto-structural correlation, bioinorganic modeling and catalysis. Metal complexes of this type having the triply-bridged the $\left[\mathrm{M}_{2}\left(\mu-\mathrm{OH}_{2}\right)\left(\mu-\mathrm{O}_{2} \mathrm{CR}\right)_{2}\right]^{2+}$ core have also been prepared and studied as structural models of the analogous diiron(II) core present in the non-heme respiratory protein hemerythrin ${ }^{5}$. The binuclear core in these complexes comprises of two carboxylate anions and a water molecule as bridging ligands. A few complexes of formula $\mathrm{Co}_{2}\left(\mu-\mathrm{OH}_{2}\right)\left(\mathrm{O}_{2} \mathrm{CR}\right)_{4} \mathrm{~L}_{4}$ have been reported in the literature ${ }^{6-9}$. The crystal structure analyses reveal that each metal centre has three facial ligands of varying $\pi$-acidity and the aqua bridges are strongly hydrogen bonded with the facial $\eta^{1}$-carboxylato ligands. In this article, we describe the synthesis and crystal structure of a new aqua-bridged binuclear cobalt(II) dichloroacetate complex having pyridine as ancillary ligands.

\section{Experimental}

The starting materials $\mathrm{Co}\left(\mathrm{NO}_{3}\right)_{2} \cdot 6 \mathrm{H}_{2} \mathrm{O}$ (E. Merck, India), pyridine, sodium dichloroacetate and methanol (Qualigens, India) were used as received. 
Solution phase UV-Visible spectrum was recorded using a Shimadzu UV-1800 spectrophotometer. The infrared spectrum was recorded in an IR Affinity-1 Shimadzu spectrophotometer for $\mathrm{KBr}$ pellets. The magnetic susceptibility measurement was carried out at 298 K on a Sherwood Mark 1 Magnetic Susceptibility Balance by Evans Method using $\mathrm{Hg}\left[\mathrm{Co}(\mathrm{NCS})_{4}\right]$ as the reference. The susceptibilities were corrected for diamagnetism using Pascal's constants. The single crystal $\mathrm{x}$ - ray diffraction data were recorded using a Bruker Smart Apex II CCD x-ray diffractometer. A suitable crystal was picked for $\mathrm{x}$-ray crystallographic work by microscopic examination. The structure was solved by direct methods (SHELXS-97) and standard Fourier techniques and refined on $\mathrm{F}^{2}$ using full matrix least-squares procedure (SHELXL-97) using the SHELX-97 package $^{10}$ incorporated in WinGX ${ }^{11}$. Two ill-fitted reflections - $(0,0,2)$ and $(1,1,0)$ - were 'omitted' (kept out) during the final refinement stages of the crystal structure. While the hydrogen atoms of the bridging aqua ligand were located in difference Fourier maps and refined isotropically, all the other hydrogen atoms belonging to crystal structure were placed at calculated positions and refined using methods incorporated in SHELXL. The structural illustrations were drawn using Ortep 3 for Windows ${ }^{11,12}$ and Diamond 8.

Preparation of $\left[\mathrm{Co}_{2}\left(\mu-\mathrm{OH}_{2}\right)\left(\mu-\mathrm{CHCl}_{2} \mathrm{COO}\right)_{2}\left(\eta^{l}-\mathrm{CHCl}_{2} \mathrm{COO}\right)_{2}(\mathrm{py})_{4}\right](\mathbf{1})$

$\mathrm{Co}\left(\mathrm{NO}_{3}\right)_{2} \cdot 6 \mathrm{H}_{2} \mathrm{O}(1.45 \mathrm{~g}, 5 \mathrm{mM})$ and sodiumdichloroacetate $(1.5092 \mathrm{~g}, 10 \mathrm{mM})$ were stirred in methanol $(30 \mathrm{~mL})$ in a round bottomed flask. Pyridine $(0.4 \mathrm{~mL}, 5 \mathrm{mM})$ was then slowly added to the reaction mixture and the stirring was continued for 4 hours to obtain a pink precipitate, which was filtered off and the filtrate was left undisturbed. Pink crystals were obtained after 4 days were collected and dried in air (Yield: 38\%). Magnetic moment: 5.65 B M.

Table 1. Crystallographic data for 1

\begin{tabular}{ll}
\hline Chemical formula & {$\left[\mathrm{Co}_{2}\left(\mu-\mathrm{OH}_{2}\right)\left(\mu-\mathrm{CHCl}_{2} \mathrm{COO}\right)_{2}\left(\eta^{1}-\mathrm{CHCl}_{2} \mathrm{COO}\right)_{2}(\mathrm{py})_{4}\right]$} \\
Empirical formula & $\mathrm{C}_{14} \mathrm{H}_{13} \mathrm{Cl}_{4} \mathrm{CoN}_{2} \mathrm{O}_{4}$ \\
Formula weight & 482.00 \\
Temperature & $296( \pm 2) \mathrm{K}$ \\
Wavelength & $0.71073 \AA$ \\
Crystal system, space group & Monoclinic, $P 2_{1} / n$ \\
Unit cell dimensions & $a=15.9657(7) \AA, b=13.0450(5) \AA, c=19.5138(8) \AA$ \\
& $\alpha=90^{\circ}, \beta=105.737(2)^{\circ}, \gamma=90^{\circ}$ \\
Volume & $3911.8(3) \AA^{3}$ \\
$Z$, Calculated density & $8,1.637 \mathrm{~g} / \mathrm{cm}^{3}$ \\
Absorption coefficient & $1.447 \mathrm{~mm}^{-1}$ \\
$F(000)$ & 1936 \\
Crystal size & $0.42 \times 0.34 \times 0.26 \mathrm{~mm}$ \\
$\theta$ range for data collection & 2.14 to $30.03^{\circ}$ \\
Limiting indices & $-22<=h<=22,-18<=k<=18,-27<=l<=27$ \\
Completeness to theta & $25.242 \approx 99.9 \%$ \\
Refinement method & Full-matrix least-squares on $F^{2}$ \\
Data/ restraints/ parameters & $11348 / 0 / 468$ \\
Goodness-of-fit $(S)^{a}$ on $F^{2}$ & 1.026 \\
$R_{\text {int }}$ & 0.0395 \\
Final $R$ indices $[\mathrm{I}>2 \sigma(\mathrm{I})]^{b}$ & $R 1=0.0595, w R 2=0.1668$ \\
$R$ indices (all data) ${ }^{b}$ & $R 1=0.0768, w R 2=0.1856$ \\
\hline${ }^{a} S=\left\{\Sigma\left[w\left(F_{o}{ }^{2}-F_{c}{ }^{2}\right)^{2}\right] /(n-p)\right\}^{1 / 2}, b=w R 2=\left\{\Sigma\left[w\left(F_{o}{ }^{2}-F_{c}{ }^{2}\right)^{2}\right] / \Sigma\left[w\left(F_{o}{ }^{2}\right)^{2}\right]\right\}^{1 / 2}, R l=\Sigma|| F_{o}|-| F_{c}|| / \Sigma\left|F_{o}\right|$ \\
\end{tabular}




\section{Results and Discussion}

The complex, $\mathrm{Co}_{2}\left(\mu-\mathrm{OH}_{2}\right)\left(\mu-\mathrm{CHCl}_{2} \mathrm{COO}\right)_{2}\left(\eta^{1}-\mathrm{CHCl}_{2} \mathrm{COO}\right)_{2}(\text { py })_{4}(\mathbf{1})$, has been prepared at room temperature in moderate yield by stirring a mixture of $\mathrm{Co}(\mathrm{II})$ nitrate hexahydrate, sodium dichloroacetate and pyridine in the 1:2:1 molar ratio. A crystal line product is obtained by allowing slow evaporation of the reaction mixture obtained after filtering off the initially formed precipitate. A well-formed crystal of $\mathbf{1}$ obtained as above has been studied by single crystal x-ray diffraction method. Crystal and structure refinement data for the complex are presented in Table 1. An ORTEP representation of the complex is shown in Figure 1.

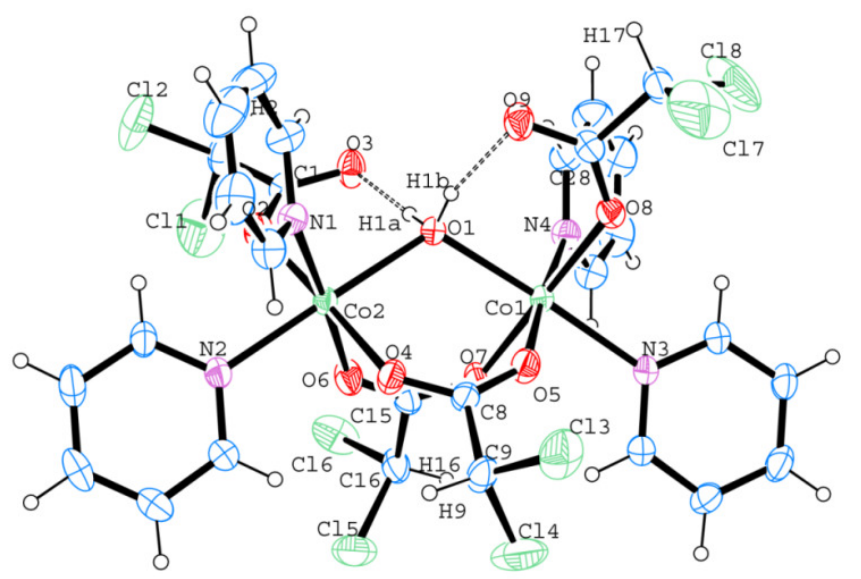

Figure 1. ORTEP diagram of $\mathbf{1}$ with thermal ellipsoids for non-hydrogen atoms drawn at $30 \%$ probability level

The compound crystallizes in the monoclinic system with space group $P 2_{1} / n$. Crystal structure of the complex reveals that the molecule consists of a dicobalt(II) unit bridged by an aqua and two dichloroacetato ligands. Each cobalt(II) centre in the complex is further coordinated to two pyridine molecules and a monodentate dichloroacetate group thereby completing the 6-coordinate environment about the metal ions. The molecule is not centrosymmetric, but both $\mathrm{Co}$ (II) centers are nearly equivalent in terms of their distorted $\mathrm{CoN}_{2} \mathrm{O}_{4}$ octahedral coordination spheres that are joined at a shared vertex by the oxygen atom of the bridging aqua ligand. The important bond distances and bond angles for this complex are given in Table 2.

It may be seen from the data presented in Table 2 that for both metal centers the distances to the $\mathrm{O}$ atom of the bridging $\mathrm{H}_{2} \mathrm{O}$ ligand are the longest among the metal-ligand bond distances. It is also noted that the two $\mathrm{Co}-\mathrm{O}(1)$ distances are unequal with $\mathrm{Co}(1)-\mathrm{O}(1)$ being longer by $0.03 \AA$ than $\mathrm{Co}(2)-\mathrm{O}(1)$. This however is not the case in general, because in several reported structures of analogous compounds of the type $\mathrm{Co}_{2}\left(\mu-\mathrm{OH}_{2}\right)(\mu-\mathrm{RCOO})_{2}\left(\eta^{1}-\right.$ $\mathrm{RCOO})_{2}(\text { py })_{4}$ the $\mathrm{Co}-\left(\mu-\mathrm{OH}_{2}\right)$ distances are equivalent or nearly equivalent ${ }^{5,6,8,9,13}$. This structural difference between 1 and other chemically analogous compounds may be traced to the unsymmetrical manner in which the $-\mathrm{CHCl}_{2}$ groups of the carboxylato ligands take part in the formation of intermolecular $\mathrm{C}-\mathrm{H} \cdots \mathrm{Cl}$ hydrogen bond contacts in the crystal structure of 1. The $\operatorname{Co}(1) \cdots \operatorname{Co}(2)$ separation of $3.7203 \AA$ in $\mathbf{1}$ is marginally longer than the corresponding separation of $3.675 \AA$ in the related compound $\mathrm{Co}_{2}\left(\mu-\mathrm{OH}_{2}\right)\left(\mu-\mathrm{CHCl}_{2} \mathrm{COO}\right)_{2}$ $\left(\eta^{1}-\mathrm{CHCl}_{2} \mathrm{COO}\right)_{2}(\mathrm{tmen})_{2}\left(\mathrm{tmen}=N, N^{\prime}, N^{\prime \prime}, N^{\prime \prime \prime}\right.$-tetramethyl-ethylenediamine $)$ containing the 
same carboxylato ligand ${ }^{14}$. In triply-bridged compounds of the type $\mathrm{Co}_{2}\left(\mu-\mathrm{OH}_{2}\right)(\mu-\mathrm{RCOO})_{2}$ $\left(\eta^{1}-\mathrm{RCOO}\right)_{2} \mathrm{~L}_{4}$ the $\mathrm{Co} \cdots \mathrm{Co}$ separation tends to be longer when the $\mathrm{R}$ group is of electron withdrawing nature. For example, this separation ${ }^{5,6}$ is $3.737 \AA$ in $\mathrm{Co}_{2}\left(\mu-\mathrm{OH}_{2}\right)\left(\mu-\mathrm{CF}_{3} \mathrm{COO}\right)_{2}$ $\left(\eta^{1}-\mathrm{CF}_{3} \mathrm{COO}\right)_{2}(\mathrm{py})_{4}$, but it is $3.548 \AA$ in $\mathrm{Co}_{2}\left(\mu-\mathrm{OH}_{2}\right)\left(\mu-\mathrm{C}_{6} \mathrm{H}_{5} \mathrm{COO}\right)_{2}\left(\eta^{1}-\mathrm{C}_{6} \mathrm{H}_{5} \mathrm{COO}\right)_{2}(\mathrm{py})_{4}$. The $\mathrm{Co}(1)-\mathrm{O}(1)-\mathrm{Co}(2)$ angle of $116.71(10)^{\circ}$ in $\mathbf{1}$ is within the normal range when it is compared with angles observed in analogous dimeric $\mathrm{Co}$ (II) complexes. The intra-molecular $\mathrm{O}-\mathrm{H} \cdots \mathrm{O}$ hydrogen bonds involving the bridging $\mathrm{H}_{2} \mathrm{O}$ molecule and the uncoordinated $\mathrm{O}$ atoms (Table 3) of the monodentate carboxylato ligands are strong $\left(\mathrm{O} \cdots \mathrm{O} \approx 2.6 \AA\right.$ and $\left.\angle \mathrm{O}-\mathrm{H} \cdots \mathrm{O} \approx 165^{\circ}\right)$ as in other compounds belonging to this class of compounds.

Table 2. Selected bond lengths $[\AA]$ and angles $\left[{ }^{\circ}\right]$ for $\mathbf{1}$

\begin{tabular}{cccc}
\hline Distances/ $\AA$ & & & \\
\hline $\mathrm{Co}(1)-\mathrm{O}(7)$ & $2.071(2)$ & $\mathrm{Co}(1)-\mathrm{O}(5)$ & $2.086(2)$ \\
$\mathrm{Co}(1)-\mathrm{O}(8)$ & $2.086(2)$ & $\mathrm{Co}(1)-\mathrm{N}(3)$ & $2.144(3)$ \\
$\mathrm{Co}(1)-\mathrm{N}(4)$ & $2.161(3)$ & $\mathrm{Co}(2)-\mathrm{O}(1)$ & $2.200(2)$ \\
$\mathrm{Co}(1)-\mathrm{O}(1)$ & $2.170(2)$ & $\mathrm{Co}(2)-\mathrm{O}(4)$ & $2.069(2)$ \\
$\mathrm{Co}(2)-\mathrm{O}(2)$ & $2.083(2)$ & $\mathrm{Co}(2)-\mathrm{O}(6)$ & $2.084(2)$ \\
$\mathrm{Co}(2)-\mathrm{N}(1)$ & $2.140(3)$ & $\mathrm{Co}(2)-\mathrm{N}(2)$ & $2.144(3)$ \\
$\mathrm{Co}(1) \cdots \mathrm{Co}(2)$ & $3.7203(5)$ & & \\
Angles/ & & & \\
$\mathrm{O}(7)-\mathrm{Co}(1)-\mathrm{O}(5)$ & $92.20(12)$ & $\mathrm{O}(7)-\mathrm{Co}(1)-\mathrm{O}(8)$ & $177.77(11)$ \\
$(5)-\mathrm{Co}(1)-\mathrm{O}(8)$ & $89.96(11)$ & $\mathrm{O}(7)-\mathrm{Co}(1)-\mathrm{N}(3)$ & $88.25(10)$ \\
$\mathrm{O}(5)-\mathrm{Co}(1)-\mathrm{N}(3)$ & $87.11(10)$ & $\mathrm{O}(8)-\mathrm{Co}(1)-\mathrm{N}(3)$ & $91.29(10)$ \\
$\mathrm{O}(7)-\mathrm{Co}(1)-\mathrm{N}(4)$ & $89.52(11)$ & $\mathrm{O}(5)-\mathrm{Co}(1)-\mathrm{N}(4)$ & $176.36(10)$ \\
$\mathrm{O}(8)-\mathrm{Co}(1)-\mathrm{N}(4)$ & $88.29(10)$ & $\mathrm{N}(3)-\mathrm{Co}(1)-\mathrm{N}(4)$ & $89.73(11)$ \\
$\mathrm{O}(7)-\mathrm{Co}(1)-\mathrm{O}(1)$ & $90.99(9)$ & $\mathrm{O}(5)-\mathrm{Co}(1)-\mathrm{O}(1)$ & $89.24(9)$ \\
$\mathrm{O}(8)-\mathrm{Co}(1)-\mathrm{O}(1)$ & $89.61(9)$ & $\mathrm{N}(3)-\mathrm{Co}(1)-\mathrm{O}(1)$ & $176.24(9)$ \\
$\mathrm{N}(4)-\mathrm{Co}(1)-\mathrm{O}(1)$ & $93.94(10)$ & $\mathrm{O}(4)-\mathrm{Co}(2)-\mathrm{O}(2)$ & $178.01(11)$ \\
$\mathrm{O}(4)-\mathrm{Co}(2)-\mathrm{O}(6)$ & $91.05(12)$ & $\mathrm{O}(2)-\mathrm{Co}(2)-\mathrm{O}(6)$ & $88.16(12)$ \\
$\mathrm{O}(4)-\mathrm{Co}(2)-\mathrm{N}(1)$ & $91.29(11)$ & $\mathrm{O}(2)-\mathrm{Co}(2)-\mathrm{N}(1)$ & $89.42(11)$ \\
$\mathrm{O}(6)-\mathrm{Co}(2)-\mathrm{N}(1)$ & $176.69(10)$ & $\mathrm{O}(4)-\mathrm{Co}(2)-\mathrm{N}(2)$ & $88.71(10)$ \\
$\mathrm{Co}(1)-\mathrm{O}(1)-\mathrm{Co}(2)$ & $116.71(10)$ & $\mathrm{N}(1)-\mathrm{Co}(2)-\mathrm{N}(2)$ & $89.76(11)$ \\
$\mathrm{O}(6)-\mathrm{Co}(2)-\mathrm{N}(1)$ & $176.69(10)$ & $\mathrm{O}(4)-\mathrm{Co}(2)-\mathrm{N}(2)$ & $88.71(10)$ \\
$\mathrm{Co}(1)-\mathrm{O}(1)-\mathrm{Co}(2)$ & $116.71(10)$ & & \\
\hline
\end{tabular}

The unit cell packing diagram shown in Figure 2 testifies that in addition to the strong intra-molecular $\mathrm{O}-\mathrm{H} \cdots \mathrm{O}$ hydrogen bonds, several inter-molecular hydrogen bonding contacts of $\mathrm{C}-\mathrm{H} \cdots \mathrm{O}$ and $\mathrm{C}-\mathrm{H} \cdots \mathrm{Cl}$ types characterize the crystal structure of compound $\mathbf{1}$ (Table 3). The $\mathrm{C}-\mathrm{H} \cdots \mathrm{Cl}$ interaction is illustrated in Figure 3 along with an energetically significant intermolecular $\pi$ - $\pi$ interaction involving the pyridine rings. It may be noted from the data presented in the table that all five distinct types of $\mathrm{C}-\mathrm{H} \cdots \mathrm{Cl}$ contacts are significant because in all cases the $\angle$ (DHA) values (D, donor and A, acceptor) are higher than $120^{\circ}$. The weaker $\mathrm{C}-\mathrm{H} \cdots \mathrm{O}$ hydrogen bridges are not shown in the table, but their existence in the crystal structure can easily be verified by handling the CIF file (made available as supplementary information) with Mercury ${ }^{15}$. Though these interactions may not be very strong individually, the presence of several such interactions clearly provides the necessary stabilization for the formation of the supramolecular network in the crystal structure of compound 1. 


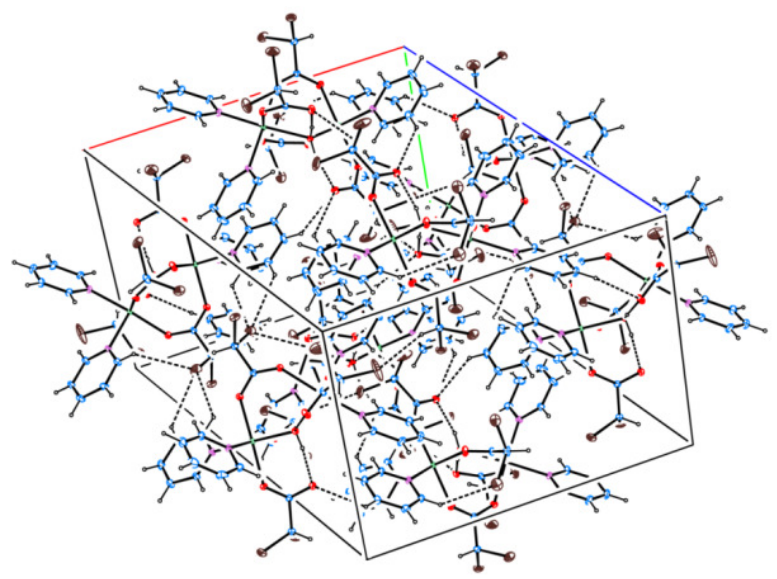

Figure 2. Unit cell packing diagram showing intra- and inter-molecular hydrogen-bonding interactions in the crystal structure of $\mathbf{1}$

Table 3. Hydrogen bonds for 1 [ $\AA$ and ${ }^{\circ}$ ]

\begin{tabular}{lllll}
\hline $\mathrm{D}-\mathrm{H} \ldots \mathrm{A}$ & $\mathrm{d}(\mathrm{D}-\mathrm{H})$ & $\mathrm{d}(\mathrm{H} \ldots \mathrm{A})$ & $\mathrm{d}(\mathrm{D} \ldots \mathrm{A})$ & $\angle(\mathrm{DHA})$ \\
\hline $\mathrm{O}(1)-\mathrm{H}(1 \mathrm{~A}) \ldots \mathrm{O}(3)$ & $0.85(5)$ & $1.76(5)$ & $2.602(3)$ & $169(4)$ \\
$\mathrm{O}(1)-\mathrm{H}(1 \mathrm{~B}) \ldots \mathrm{O}(9)$ & $0.83(4)$ & $1.82(5)$ & $2.634(3)$ & $163(4)$ \\
$\mathrm{C}(9)-\mathrm{H}(9) \ldots \mathrm{Cl}(2) \# 1$ & 0.98 & 2.92 & $3.893(4)$ & 169.6 \\
$\mathrm{C}(13)-\mathrm{H}(13) \ldots \mathrm{Cl}(4) \# 2$ & 0.93 & 2.89 & $3.509(5)$ & 125.0 \\
$\mathrm{C}(14)-\mathrm{H}(14) \ldots \mathrm{Cl}(4) \# 2$ & 0.93 & 2.86 & $3.501(4)$ & 127.1 \\
$\mathrm{C}(16)-\mathrm{H}(16) \ldots \mathrm{Cl}(8) \# 3$ & 0.98 & 2.60 & $3.520(4)$ & 157.3 \\
$\mathrm{C}(27)-\mathrm{H}(27) \ldots \mathrm{Cl}(4)$ & 0.93 & 2.95 & $3.635(4)$ & 131.8 \\
\hline
\end{tabular}

Symmetry transformations used to generate equivalent atoms: ${ }^{\#} 1-x+3 / 2, y+1 / 2,-z+1 / 2,{ }^{\#} 2-x+2,-y+1$,$z+1,{ }^{\#} 3-x+5 / 2, y-1 / 2,-z+1 / 2$

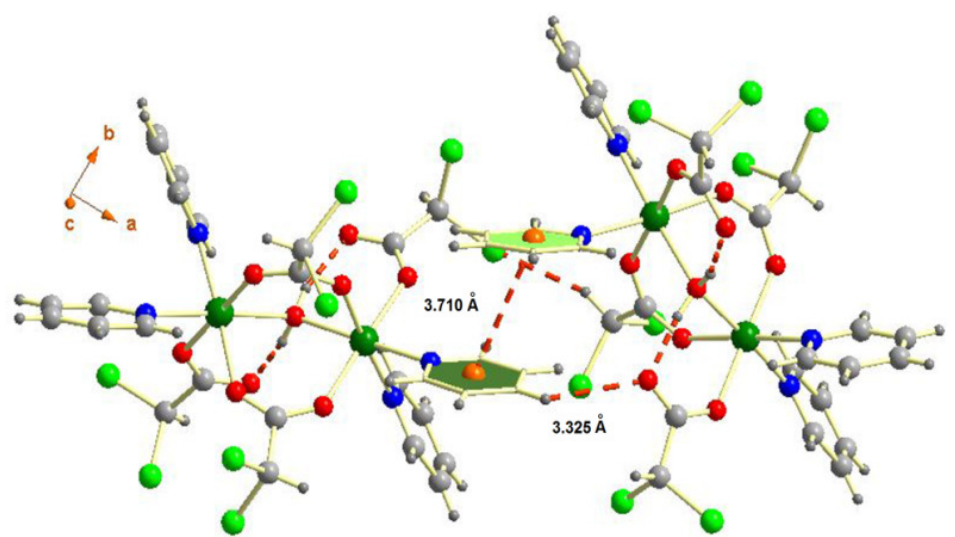

Figure 3. Intra-molecular $\mathrm{O}-\mathrm{H} \cdots \mathrm{O}$ and intermolecular $\mathrm{C}-\mathrm{H} \cdots \mathrm{O}, \mathrm{C}-\mathrm{H} \cdots \mathrm{O}$ and $\pi-\pi$ interactions in the crystal structure $\mathrm{Co}_{2}\left(\mu-\mathrm{OH}_{2}\right)\left(\mu-\mathrm{CHCl}_{2} \mathrm{COO}\right)_{2}\left(\eta^{1}-\mathrm{CHCl}_{2} \mathrm{COO}\right)_{2}(\mathrm{py})_{4}$

\section{Supplementary Information}

Crystallographic data on $\mathbf{1}$ in CIF format (CCDC 1555406) are available at www.ccdc.cam.ac.uk 


\section{IR Spectral Data}

The $\mathrm{KBr}$ phase IR spectrum of the compound 1 (Figure 4) shows distinct bands, some of which are assignable to specific vibrations. The strong band occurring at $1682 \mathrm{~cm}^{-1}$ may be attributed to the presence of the unidentate carboxylate anions as ligands. However, assignments for the $\left[\mathrm{v}_{\mathrm{asym}}\left(\mathrm{COO}^{-}\right)\right]$and $\left[\mathrm{v}_{\mathrm{sym}}\left(\mathrm{COO}^{-}\right)\right]$carboxyl stretching vibrations of the bridging ligands cannot be made with certainty due to the expected occurrence of a pyridyl ring vibration at $\sim 1600 \mathrm{~cm}^{-1}$ where the $\left[v_{\text {asym }}\left(\mathrm{COO}^{-}\right)\right]$vibration is also expected to occur. While the band at $1385 \mathrm{~cm}^{-1}$ is likely to be due to $\left[\nu_{\text {sym }}\left(\mathrm{COO}^{-}\right)\right]$, the weaker but sharp bands at 1485 and $1443 \mathrm{~cm}^{-1}$ are characteristic of pyridine ring stretching vibrations.

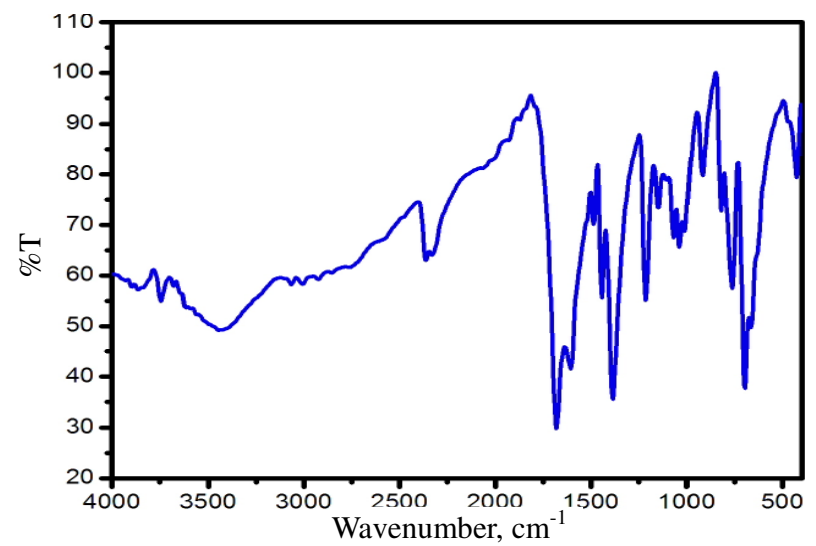

Figure 4. $\mathrm{KBr}$ phase IR spectrum of $\left[\mathrm{Co}_{2}\left(\mu-\mathrm{OH}_{2}\right)\left(\mu-\mathrm{CHCl}_{2} \mathrm{COO}\right)_{2}\left(\eta^{1}-\mathrm{CHCl}_{2} \mathrm{COO}\right)_{2}(\mathrm{py})_{4}\right](1)$

\section{UV-Vis Spectral Data}

In methanol, the UV-vis spectrum of complex 1 (Fugre 5) shows a strong band at $525 \mathrm{~nm}$ along with another that appears as a well-developed shoulder at $292 \mathrm{~nm}$. The band at $292 \mathrm{~nm}$ is due to $\pi \rightarrow \pi^{*}$ transition of pyridine ligand. On the other hand, the band at $525 \mathrm{~nm}$ can be assigned to the $d$-d transition ${ }^{4} \mathrm{~T}_{1 \mathrm{~g}}(\mathrm{~F}) \rightarrow{ }^{4} \mathrm{~T}_{1 \mathrm{~g}}(\mathrm{P})$ involving the high-spin octahedral Co(II) coordination spheres. The shoulder appearing at $\sim 660 \mathrm{~nm}$ is also likely to be of ligand field origin.

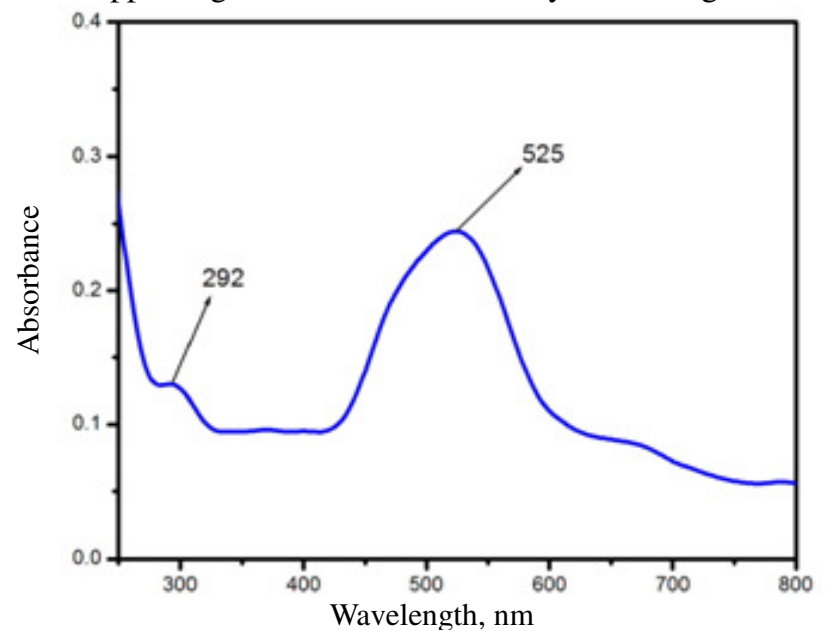

Figure 5. UV-visible spectrum of $\left[\mathrm{Co}_{2}\left(\mu-\mathrm{OH}_{2}\right)\left(\mu-\mathrm{CHCl}_{2} \mathrm{COO}\right)_{2}\left(\eta^{1}-\mathrm{CHCl}_{2} \mathrm{COO}\right)_{2}(\mathrm{py})_{4}\right](\mathbf{1})$ 


\section{Conclusion}

The complex $\left[\mathrm{Co}_{2}\left(\mu-\mathrm{OH}_{2}\right)\left(\mu-\mathrm{CHCl}_{2} \mathrm{COO}\right)_{2}\left(\eta^{1}-\mathrm{CHCl}_{2} \mathrm{COO}\right)_{2}(\text { py })_{4}\right](\mathbf{1})$ is a binuclear cobalt(II) complex having two bridging carboxylate groups and the aqua bridge. The structure of the complex is structurally similar to the active site of aminopeptidase and thus can be useful for understanding some of the relevant biological systems. Under our reaction conditions, the dichloroacetato ligand prefers to form compound 1 rather than a member of the closely related complexes of the type $\left[\mathrm{M}_{2}\left(\mu-\mathrm{CHCl}_{2} \mathrm{COO}\right)_{2}\left(\eta^{2}-\mathrm{CHCl}_{2} \mathrm{COO}\right)_{2}(\mathrm{py})_{4}\right]^{16}$.

\section{Acknowledgement}

We are thankful to UGC, BSR-RFSMS fellowship for financial support to MG and SAIF, Gauhati University for single crystal x-ray diffraction data.

\section{References}

1. Ye B H, Williams I D and Li X Y, J Inorg Biochem., 2002, 92(2), 128-136; DOI:10.1016/S0162-0134(02)00496-8

2. Hikichi S, Yoshizawa M, Sasakura Y, Akita M and Moro-Oka Y, J Am Chem Soc., 1998, 120(40), 10567-10568; DOI:10.1021/ja9818371

3. Hagen K S, Lachicotte R and Kitaygorodskiy A, J Am Chem Soc., 1993, 115(26), 12617-12618; DOI:10.1021/ja00079a064

4. Reynolds III R A, Dunham W R and Coucouvanis D, Inorg Chem., 1998, 37(6), 1232-1241; DOI:10.1021/ic971537p

5. Burley J C and Prior T J, Acta Cryst., 2005, E61, m1422-m1424;

DOI:10.1107/S1600536805019586

6. Karmakar A, Sarma R J and Baruah J B, Polyhedron, 2007, 26(6), 1347-1355;

DOI:10.1016/j.poly.2006.11.001

7. Das B K and Chakravarty A R, Inorg Chem., 1991, 30(26), 4978-4986;

DOI:10.1021/ic00026a024

8. Hudác J, Boča R, Moncol J and Titiš J, Inorg Chim Acta, 2013, 394, 401-409;

DOI:10.1016/j.ica.2012.09.001

9. Pruchnik F P, Dawid U and Kochel A, Polyhedron, 2006, 25(18), 3647-3652;

DOI:10.1016/j.poly.2006.07.023

10. Sheldrick G M, Acta Cryst., 2008, A64, 112-122; DOI:10.1107/S0108767307043930

11. Farrugia L J, J Appl Cryst., 1999, 32, 849-854; DOI:10.1107/S0021889812029111

12. Brandenburg K, Diamond, Crystal Impact GbR, Bonn, Germany, 2006.

13. Crockery R W and Hockless D C R, Acta Cryst., 1997, C53, 840-843; DOI:10.1107/S010827019700259X

14. Ahgrén M, Hämäläinen U and Turpeinen U, Finn Chem Lett., 1983, 125.

15. Macrae C F, Edgington P R, McCabe P, Pidcock E, Shields G P, Taylor R, Towler M and van de Streek J, J Appl Cryst., 2006, 39, 453-457;

DOI:10.1107/S002188980600731X

16. Bharali S J and Das B K, Acta Cryst., 2016, E72, 1549-1553;

DOI:10.1107/S2056989016015589 